\title{
Costs and Benefits of Environmental Change: Tourism Industry's Responses in Arctic
}

\section{Finland}

Kaarina Tervo-Kankare a Corresponding author

Eva Kaján a

Jarkko Saarinen a,b

a Geography Research Unit, University of Oulu, Finland

b School of Tourism and Hospitality, University of Johannesburg, South Africa

Kaarina Tervo-Kankare

email: kaarina.tervo-kankare@oulu.fi

Geography Research Unit, P.O. Box 3000, 90014 University of Oulu, Finland

Eva Kaján

email: eva.kajan@oulu.fi

Geography Research Unit, P.O. Box 3000, 90014 University of Oulu, Finland

Jarkko Saarinen

email: jarkko.saarinen@ oulu.fi

Geography Research Unit, P.O. Box 3000, 90014 University of Oulu, Finland

\section{Acknowledgements}

This work was supported by the Academy of Finland under the CLICHE-project (Impacts of Climate Change on Arctic Environment, Ecosystem Services and Society). 


\begin{abstract}
Recent research has focused on the impacts of environmental change to tourism. In particular, the perceived costs of climate change have been increasingly studied. However, the relationship between costs and benefits resulting from the changing environmental conditions for the industry has been less examined. This paper identifies the locally observed changes in the natural and socioeconomic environments and aims to analyse the financial costs and benefits to tourism businesses in two tourism-dependent communities in northern Finland. The specific focus is on adaptation and adaptive management in a tourist destination scale. Adaption is understood as an investment creating not only implementation costs, but potentially also benefits for tourism operations. Research materials were collected among tourism and tourism-related businesses through 41 semistructured thematic interviews. Results indicate that the evaluated benefits of environmental change seem to exceed those of costs. This conforms to the ongoing discourse of climate change-tourism relations associated with the Arctic region where both awareness and vulnerability to change are considered relatively high but the level of responses, i.e. adaptation, low. These results can help to further identify the most vulnerable sectors in tourism and assist entrepreneurs preparing for environmental and climate change. However, the paper concludes that while global environmental change, with specific adaptive management strategies, may create local short-term direct benefits for the industry, a long-term sustainability of tourism in the Arctic calls for mitigation responses to climate change.
\end{abstract}

Keywords: environmental change, climate change, adaptation, adaptive management, costs and benefits, Lapland, Arctic, tourism, community, SMEs 


\section{Introduction}

The relationship between tourism and environmental change has been studied for a relatively long time (see Mathieson \& Wall, 1982). As one of the largest sectors of the global economy (UNWTO, 2015), the tourism industry is a major contributor to environmental change, including socio-cultural and economic issues. Thus, the impacts of tourism activities have formed the core focus of research (Gössling, 2002; Holden, 2006; Scott et al., 2013). In tourism research, the management of the impacts and governance of tourism development towards sustainability have formed the main aims in recent decades (Saarinen, 2014). At the same time, it has been widely realised that tourism is largely dependent on and affected by environmental conditions (Gössling \& Hall, 2006), as well as highly vulnerable to any changes taking place within its physical, socio-cultural or economic environments. This, in principle, makes the need for sustainability management important for the industry itself (Bramwell \& Lane, 2011; Hall, 2013) as the ongoing global environmental change (GEC) may have serious consequences for the future prospects of tourism.

In recent decades there has been an increasing interest in the impacts of global climate change (GCC) on tourism (see Gössling \& Hall, 2006; Reddy \& Wilkes, 2013). Indeed, climate is often seen as one of the most important resources of a tourist destination (Rutty \& Scott, 2010). Instead of mitigation, i.e. limiting and regulating the impacts, this interest has mainly focused on adaption perspectives. A Google Scholar search, for example, provides well over twice as many hits for 'tourism and adaptation' than 'tourism and mitigation'. This also reflects the recent focus in the Intergovernmental Panel on Climate Change (IPCC, 2014) assessments and the United Nations Framework Convention on Climate Change (UNCCC) Paris Agreement (UNCCC, 2015) emphasising the urgent need for adaptation and focus on vulnerability issues. Therefore, while mitigation is critical for long-term survival, coping with the estimated, inevitable changes has become crucial in many parts of societies and in different scales ranging from local to transnational governance (see Bramwell \& Lane, 2011; Scott et al., 2013).

In tourism studies, adaptation, referring to actions aiming to reduce the negative effects (and to benefit from the positive effects) of climate change (Smit \& Wandel, 2006), has been studied for decades (see Kaján \& Saarinen, 2013; Scott; Hall \& Gössling, 2012; Wall et al., 1986). The studies have often focused on the adaptation perceptions, attitudes and needs of tourism operators (Brouder \& Lundmark, 2011; Hall, 2006; Hopkins, 2014; Tervo, 2008; Rauken \& Kelman, 2012; Wolfsegger 
et al., 2008), and on the determinants of adaptation at the business' level (Hoffmann et al., 2009). Typically, the scale of analysis has been local and based on a single tourism operator or business sector, such as down-hill skiing (e.g. Dawson \& Scott, 2013; Haanpää, Juhola \& Landauer, 2014; Morrison \& Pickering, 2013). These kinds of studies are important in order to develop a basic understanding of climate change-tourism -relations and adaptation needs in the industry.

In this paper, however, environmental change in relation to tourism is approached in the wider destination context. Thus, the research focus includes the core primary tourism businesses, but there are also enterprises, which receive tourism-related income, but for whom tourism may not be a primary, but secondary, source of revenue. They may also serve the primary tourism businesses working directly with tourists' consumption needs. These secondary tourism businesses, such as retail, transportation or janitorial services are economically important and typical for tourism destinations (see Saarinen, 2003). They may have similar or different vulnerabilities to climatic conditions than core tourism operators. Although economically important and highly typical for tourism destinations, hardly any information exists about climate change adaptation among them (see Kaján, Tervo-Kankare \& Saarinen, 2014). Therefore, this article makes an effort to move away from purely sectoral adaptation efforts to a more destination-based approach, which represents a novel approach. This means including all the businesses operating in a tourism destination which have a full or partial, direct or indirect role, in tourists' consumption. Here the 'destination' refers to a relatively coherent spatial unit that includes tourism (primary) and tourism-related (secondary) businesses and other actors collaborating in co-production, local value-chains and/or marketing (see Saarinen, 2004).

Understanding the destination beyond core tourism businesses alone is crucial when considering the cost and/or benefits of global environmental change in tourism or the future prospects of tourismdependent communities in general. A wider perspective is needed which includes socio-cultural and economic (and political) environments, the characteristics (such as social capital), and changes of which may affect adaptation and adaptive capacity to environmental changes (Aall, 2012; Adger, 2003; Scott, Hall \& Gössling, 2012; Tervo-Kankare, 2012). In addition, environmental change in relation to tourism is approached here from the perspectives of costs and benefits. The combined costs-benefits approach has not been widely applied to tourism research, with the majority of existing tourism studies focusing on the cost element alone (e.g. Kaján et al., 2014; Morrison \& Pickering, 2013). 
Due to the current modes of governance, the focus on businesses and their perceptions, preferences and decision-making can be seen as increasingly important perspectives in GEC/GCC studies. In general, governance represents a new form of public management structured along market (or quasi-market) organisational models (Jessop, 2002; Rhodes, 1996) where governing structures no longer focus primarily on the traditional roles of public sector government (Hall, 2011). Instead, they increasingly incorporate 'a range of interests drawn from the private sector' (Amore \& Hall, 2016, p. 2). Thus, decision-making and responsibilities in adaptation (and mitigation) are also devolved to markets and private-sector operators in a local scale (see Nalau et al., 2015). As a result there is a strong emphasis that adaptation 'should be decentralised to the lowest level of governance' (Marshall, 2008, p. 80).

In general, this governance perspective highlights the need to understand how businesses operate and perceive the potential, or existing, costs and benefits of global environmental change. Here the identification of costs and benefits is based on a quantitative approach. Quantitative aims and results may often be more understandable for the tourism operators (mainly small- and medium sized enterprises, SMEs) and especially for policy-makers (see Ingirige, Jones \& Proverbs, 2008; Veal, 2006) as decision-making processes are easier to complete based on numerical than on qualitative outcomes. However, this approach also involves challenges as many issues and changes related to the operational environment of businesses are difficult to quantify. Moreover, this article analyses tourism stakeholders' understandings about the changes taking place in socio-economic environment and their relationship with the changes in natural environment (see Eriksen, Nightingale \& Eakin, 2015). Therefore, 'environmental change' refers to not only climate change, especially when focusing on costs and benefits, but also to other changes in the operational 'local' environment.

\section{Tourism and Environmental Change: Adaptation Perspectives}

Growing public awareness and discussions of global climate change have created an intensified interest in environmental change and tourism related research and policy-making (Becken \& Clapcott, 2011; Bramwell \& Lane, 2008). This interest has mainly focused on adaptation perspectives, and the concept of 'adaptation' is widely discussed in the literature (see Aall \& Hoyer, 2005; Adger, Arnell \& Tompkins, 2005; Ford \& King, 2015; Füssel \& Klein, 2006; Pelling, 2011; Scott \& Becken, 2010). The concept focuses on how a unit, or a system, aims to adapt/adapts to 
change through transforming its operations (Kelly \& Adger, 2000; Pielke, 1998), and is usually seen as a local scale response (see Nalau et al., 2015). In addition, however, adaptation and related actions should contribute to climate resilient development which increases the systems' (climate and weather) stress tolerance and the ability to reorganize or continue operations in changing environments (Lew, 2014). In this respect adaptation is a critical aspect to resilience and together (Espiner, Orchiston \& Higham, 2017) they can enhance sustainable development locally and in the wider tourism system and societies.

On one hand, adaptation generates costs which may in certain cases hinder or even prevent action (see Steiger \& Stötter, 2013). In addition to the problem of not knowing the future unit or system adapting to change, the challenge in estimating the costs of change lies in the complexity of the adaptation process (Kaján et al., 2014). It is also sometimes difficult to define what is considered adaptation and which activities are related to, and considered to be part of, the 'normal' product development in tourism businesses. For example, artificial snowmaking can represent an adaption mechanism to changing environmental conditions in some locations (Haanpää, Juhola \& Landauer, 2014; Träwöger, 2014). However, many destinations have traditionally used it, and increasingly continue to do so, to extend the skiing season based on normal i.e. natural winter conditions.

On the other hand, while adaptation represents a cost, it aims to create benefits for the units and systems transforming their activities in order to manage operations and survive changing environment. Therefore, adaptation can be interpreted as an investment where the exact net benefits are difficult to measure. In particular, the benefits of adaptation towards estimated changes in the future are extremely difficult to study due to the conceptual ground of adaptation: as the future characteristics of 'units or systems' adapting to change are not known in present, it is highly hypothetical to evaluate the matter. Therefore, this research limits its focus on the current perceived changes in the environment and adaption towards those changes. In addition to adaptation being beneficial to enterprises (at least in the long run), the environmental changes may similarly bring with them direct benefits. These benefits may be manifested, for example, in the form of competitive advantage over other enterprises and destination regions, or decreasing infrastructural costs (e.g. warming decreasing the use of heating energy) (Saarinen \& Tervo, 2006).

The focus on businesses and their perceptions, preferences, and decision-making is increasingly important perspective in GEC/GCC studies. This is due to the current modes of neoliberal governance emphasising (or assuming) the key and active role of markets to deal with their 
environmental consequences and possible negative externalities of economic growth for environment (see Jessop, 2002, Rhodes, 1996). Based on this, governing structures increasingly incorporate certain interests that originate from the private sector (Amore \& Hall, 2016; see Hall, 2011). Thus, decision-making and responsibilities in adaptation (and mitigation) are also devolved to markets and private-sector operators, which highlight the issue of adaptive management in businesses. In general, adaptive management studies have focused on resource and species management contexts (e.g. Armitage et al., 2009; Berkes, Colding \& Folke, 2000; White, Cornett \& Wolter, 2017), but it can be applied to businesses and their relations to changing environments.

Adaptive management is called 'adaptive' as it recognises that environmental conditions are in constant change. This requires communities and societies to respond by continuously evolving (Berkes, Colding \& Folke, 2000). In general, adaptive management can be organised as either passive or active adaptive management (Table 1), depending on how learning and knowledge creation take place. Passive adaptive management is reactive and involves learning based on experienced situations and only if it improves decision outcomes. In contrast, active adaptive management involves proactive learning and decisions improving knowledge and learning are valued (Walters, 1986). Both approaches involve learning but active adaptive management is more driven by search for knowledge and information before decisions and actions while in passive adaptive management, learning is more based on experience.

Insert Table 1. about here.

Tourism is an industry, where small enterprises dominate the field, and consequently the costs of any 'extra-curricular' activity may turn into an insurmountable obstacle. Therefore, it is important to be able to assess the sources and amount of costs emerging from the consequences of change. In addition, as Smit et al. (2000) have stated, adaptation to climate change in tourism is not restricted to adjusting to changes in the long term mean climate variables only, as also variability, which includes the weather extremes, is changing. Thus, in tourism, where different kinds of climate variability play an important role in the day-to-day operations (Becken, 2012; Rauken \& Kelman, 2012; Shih, Nicholls \& Holecek, 2008; Tervo, 2008), adaptation is not limited to temperature differences only. Research has shown that snow conditions, occurrence and timing of extremely cold, hot, windy and rainy days, are important factors in nature-based tourism industry (see Csete \& Szécsi 2015; Hopkins, 2014; Nicholls, Holecek \& Noh, 2008; Rauken et al. 2010). These previous studies have also indicated that the level of climate change adaptation is rather low in many tourism 
businesses (Cheablam \& Shrestha 2015; Haanpää et al., 2014; Hall, 2006; Matasci et al. 2014; Tervo-Kankare 2011; Träwöger, 2014). Consequently, detailed information about the costs or benefits of (non-existing) adaptation is difficult to obtain. When only little information is available, temporal and spatial analogues could help in developing a basic understanding of the future conditions and the development needs of nature-based industries (Ford et al., 2010).

\section{Study Design, Methods and Data}

The study was conducted in Saariselkä (located in Inari municipality) and Kilpisjärvi (located in Enontekiö municipality) in late 2013 and early 2014. Both destinations are located in Finnish Lapland and can be considered peripheral and Arctic tourism destinations located in high latitudes (Figure 1). Even though tourism in both destinations is, to some extent, year-round tourism, they have high seasons: winter in Saariselkä and summer in Kilpisjärvi (Laatutiimi 2011; Enontekiön matkailualueen turvallisuussuunnitelma 2013). However, the activities they provide for tourists have similarities, with the exception of Saariselkä having a down-hill skiing centre. In both destinations, nature-based tourism has an important role as a provider of work and income to people and communities nearby: tourism has enabled development in the villages, for example, by bringing in and maintaining services that would not be possible on the basis of permanent population, and they are dependent on tourism income (Kaján, 2014; Saarinen, 2003). Both destinations attract visitors from Finland and abroad, and the origin of tourists affectsthe seasons. In Saariselkä, for example, the tourists from Asia characterise early winter season (and also summertime) while the Russians arrive in great numbers in early January. Finnish tourists' main seasons occur during the ski-holiday season in spring (February-March) and during the autumn foliage in the fall (Laatutiimi, 2011).

Empirical data was collected through semi-structured interviews, which lasted between 10-60 minutes and through an Internet-based survey in late 2013 and early 2014. The target group for the interviews and the survey were local businesses, which operated in the postal code areas of Saariselkä and Kilpisjärvi. In both communities, all businesses whose contact information was available were contacted and requested for an interview either by phone or email. Those, who were not reached at the original stage, were sent the questions through either email or with a link to an online survey. The interview questions and the online-survey were identical. They dealt with respondents' perceived experiences concerning changes in economic, socio-cultural and ecological 
environments during the last five years, the costs and benefits occurring because of weather-related events during that time slot, and with the basic background information of the businesses (season, activities, revenues, etc.). The questions did not explicitly focus on climate change, but on weather variations and phenomena and their subsequent impacts. This approach is often used in climate change -studies as it is more comprehensible and less value-loaded for participants than the notion of climate change (see e.g. Saarinen \& Tervo, 2006).

Figure 1 about here. Map of the study area.

In Saariselkä, 18 businesses were interviewed in person, and five businesses participated via the online version of the survey. Altogether, these 23 businesses represent 33 percent of the local businesses registered in Saariselkä, where 69 businesses were operating in 2011 (Statistics Finland, 2014). According to the statistical database (Statistics Finland, 2014), Kilpisjärvi has 21 registered businesses of which 15 were interviewed face-to-face and three via email $(n=18)$. This represents 86 percent of all the businesses in Kilpisjärvi.

Both communities are located in rural Finland and are small in size. Their special characteristics include strong entrepreneurial activity, and a dependency on tourism and nature as a livelihood (Kaján, 2014). All interviews were tape-recorded (when allowed by the interviewees) and the data was compiled and partly transcribed to an Excel file for further processing. The collected data was analysed via qualitative content analysis, where responses were studied in order to find similarities, common or shared views and themes (e.g. phenomena that could be related to climate change on the basis of scientific knowledge about the topic), and linkages between them. Classification and quantification of the responses was utilized when possible. As the sample size is rather small, no statistical analyses were conducted - only certain classifications and distributions were examined using statistical methods such as cross-tabulation and non-parametric tests.

Overall, the number of interviewed businesses $(n=41)$ gives a 47 percent response rate among all businesses in Kilpisjärvi and Saariselkä. The majority of the participating businesses were from the 'accommodation and restaurant sector', followed by 'combination businesses' (enterprises that provide services falling under two sectors) and 'retail and programme services' (see Table 2). The enterprises were classified on the basis of their dominating activity if the business had one or two clear ones. Thus, the group 'Other' consists of businesses that either offered a multitude (more than two) of equally important activities, or activities that did not fall in the main categories (e.g. 
translation, janitorial services). Over 75 percent of all the businesses were willing, and able, to give their annual turnover figures. In addition, the turnover figures for three businesses were available from business-related open databases. As the aim of the paper is to compare the risen expenses and/or financial benefits occurred by different weather phenomena against the annual turnover, the partially limited availability of turnover figures has, to some extent, restricted the analysis.

Insert Table 2. about here.

The study utilizes a temporal analogues approach, which is a commonly used method in climate change studies (Ford et al., 2010; Rutty et al., 2017), including tourism research. Both Dubois and Ceron (2006) and Dawson et al. (2009) have utilised and examined the usability of analogues in tourism adaptation studies. Temporal analogues, in comparison to basic climate change future scenarios, allow the consideration of how human systems operate 'within a framework of coexisting stresses' (Rutty et al., 2017, p. 197), i.e. the human behaviour and reactions to diverse climate phenomena. Therefore, analogues also consider the socio-economic environment that affect and guide human behaviour. This approach is important in studies aiming to understand the areas of extra costs and benefits: sectors, seasons, and types of costs and benefits (labour-related, programmes, infrastructure, sales).

\section{Changing Environment and Adaptation in Kilpisjärvi and Saariselkä}

\section{Perceived Changes in Natural Environment}

In the two destinations, the majority of the respondents (88\%) had experienced changes in their natural environment. Mostly, the observed changes related to issues that originated from changes in the climatic conditions (Table 3). They can be categorised as changes taking place in relation to seasons, weather conditions in general, flora and fauna, and other. The 'other' category includes separate or sporadic matters such as water shortages. To some extent, the season- and weatherrelated changes are interrelated; therefore this classification should not be interpreted as categorical. In addition, as humans often experience 'weather' rather than 'climate', the categorisation is somewhat approximate rather than precise interpretation of the experienced changes.

Geographically, the notions about changes did not vary considerably. 
Table 3. here.

Though sometimes the observed phenomena were conflicting, the most common issues referred to changes in snow cover. What is interesting is the diversity of observed phenomena within a relatively short time period (five years, compared to the timeframe associated with climate change in general). The respondents did not always attach positive or negative significance to the observed changes in the context of their business. Therefore, the changes cannot be categorised according to their relevance in terms of infrastructure, sales, labour or programme management. Instead, the changes were mentioned in relation to their personal lives.

\section{Perceived Changes in Socio-Economic Environment}

As environmental changes do not exist in an isolated vacuum, the interviews also gathered information about locally experienced changes outside the climate change narrative and natural settings alone. Out of all respondents, 88 percent had observed changes in their socio-economic environment during the last five years. Four thematic groups emerged from the material: infrastructure, economic issues, sales and customers. When compared to changes in natural environment, the respondents were more often able to pinpoint the positive and negative impacts of these changes.

The positive infrastructural changes included increased diversification of tourism services and the renewed network of skiing and hiking routes in both locations. Also, increased permanent housing was seen as positive as it contributes to the destination's stability. Despite the increase in construction, the built environment was still seen as spacious and well-built in Saariselkä. The main negative point related to infrastructure in Saariselkä concerned the local airport services and flight connections, which were considered unfair in comparison to competitive destinations (expensive connections) and also unreliable to some extent (mainly due to airline strikes). Other negative aspects were linked with power issues and dominance among the accommodation establishments. Certain businesses were considered to have power over the others and it was noted in both destinations, that there was a certain social distance between the newcomers and more permanent residents. It was also stated that the hotel chains were not so committed to local tourism development and had other values than local establishments. Electricity power cuts were an issue in both communities. Both locations also perceived a decrease in tourism services. Paradoxically in 
Kilpisjärvi this was partially the result of an outmigration of population and not so much due to the declining attractiveness as a tourism destination as is often the reason for decreasing services.

The global financial crisis that started in 2007, and the recession that followed till the fieldwork period in 2014, were quoted to be noticeable factors in terms of both local and global economics and resulted in less sales and difficulties in planning. Also changes in taxation were a negative factor affecting the socio-economic development in both locations. Growth factors were only observed in Saariselkä, whereas in Kilpisjärvi, it was stated that the unknown status of the potential new national park in the immediate area was stalling further investments (the Finnish government decided against establishing the national park due to local resistance in the spring of 2014 after fieldwork).

The positive sales and customer related factors in Kilpisjärvi were associated with a more diverse customer base through an increase in Russians and independent tourists. Also, Saariselkä had observed an increase in visitation from Russian markets, and foreign markets were stated not to be affected by the recession and their numbers had in fact increased. Also, the amount of Norwegians coming for holidays and taking advantage of trans-boundary shopping opportunities increased. This was coupled with an increase in Finnish tourists. Despite the diversified customer base, the changes in tourists' typology were also considered as negative socio-economic development, as both destinations were experiencing losses in their main segments. The main segment has traditionally been the independent cross-country skiers, but this group of tourists is getting older and hence smaller. The activity needs of the younger generation are different resulting in the permanent decrease in the previously known main segment.

Concerns were related to the high dependency on the Norwegian market and the currency fluctuations concerning Norwegian crown (krone). It was also remarked that even though Norwegians were a very dominant group, the economic benefits did not disperse well throughout the community. The increased amount of tourists interested in snowmobiling was seen as both beneficial and distracting as it was creating conflicts between un-motorised and motorised programmes. The spring tourism season was perceived to be shorter and creating pressure on other seasons. In Saariselkä, it was stated that the combination of airline strikes, recession and poor sales were detrimental to the destination. Tourism development was also affected by increased international competition. The current trend also indicated an increase in small, rather than large, groups. 
Altogether, 78 percent of the respondents indicated that they had benefitted financially from the exceptional weather conditions taking place during their main season. Almost half of them (47\%; which is $37 \%$ of all respondents) were able to give a numerical estimation of the benefit. In general, the financial benefits were rather insignificant, mostly varying between 0.1 to 2 percent of the annual turnover (see table 4). Occasionally, the benefits were much higher, reaching 33 percent. In all but one case, the end result of the benefits was manifested as increased sales. Infrastructural benefits were mentioned once, in relation to decreasing energy demand. Programme managementor labour-wise no direct benefits occurred.

Insert Table 4. about here.

In general, the positive impacts were related to two broad themes. The first is related to experienced conditions, which mainly consisted of local weather phenomena happening under normal variability (mentioned 17 times). Also, weather and climatic phenomena or changes taking place in visitors' home regions (mentioned 4 times) fall under this category. These phenomena were considered as 'normal' and did not raise much discussion. On the contrary, the second theme is related to emerging phenomena, where local climatic conditions can be associated with climate change (mentioned 16 times) referring to more permanent changes.

The experienced phenomena mainly referred to the extremes of 'good' and 'bad' weather, and to the quick weather fluctuations. Sunny weather increased the outdoor sales whereas rain and storms attracted consumers to inside activities. In general, the benefits occurred at the expense of someone else's business. Estimating the significance of the benefits under this category seems to be difficult: only in two out of 17 cases (12\%) the interviewees were able to give numerical value to the benefit (in relation to annual turnover). In addition, the weather and climatic phenomena taking place in visitors' home regions were mainly related with the climatic counterpoints in tourism: people want to travel to north to escape the heat or to see snow in occasions, when no snow is present at home. In two out of four cases, the respondents gave a numerical value for the benefit. 
The emerging phenomena referred to the changing amounts of snow and warming and the increasing number of unusual weather-related phenomena. This kind of phenomena can be related to climate change, as they are, according to climate science, signs of global climate change in the study area. Mostly, the benefits regarding the amount of snow referred to the great amount of snow, which causes more work and results in more income. It also increases customer satisfaction and makes the destinations more attractive through relative snow security. Moreover, the respondents were able to estimate the benefits under this category as 44 percent provided a numerical estimate for the benefit. Other benefits from the emerging phenomena included increased indoors sales due to bad weather (e.g. stormy/rainy weather that may prevent outdoor activities) and lower energy costs due to warming.

In terms of GEC-related benefits per sector, the results are the following in a descending order: Other (average benefits 16.8\%), Accommodation and restaurant (10.9\%), Combination enterprises (3.2\%), Transport (0.5\%), Recreation and programme services $(0.1 \%)$, and Retail $(0.02 \%)$. To conclude, 5 out of $6(83 \%)$ Recreation and Programme Service businesses had benefitted from climate and weather phenomena, while in Accommodation and Restaurant services 8 out of 12 (67\%) entrepreneurs reported benefits. Under the categories Retail and Transport services all of the businesses $(100 \%)$ had received extra income due to climatic and weather conditions. Also in the Other and Combination sectors, the majority of businesses (71\% and $75 \%$ respectively) had experienced benefits. The average benefit created by changing environment, including climate change, among the businesses was $\mathbf{7 . 3}$ percent in relation to annual turnover.

\section{Costs of Environmental Change}

The root-causes for extra costs were connected to bad weather, unreliable weather forecasts, snowrelated issues, warm weather, rain, and wind (see table 5). These weather-related extra expenses can be divided into four categories: sales, infrastructure, tourism programmes and labour costs. Though the sample size is fairly small, there is indication that the actual costs accrued and the financial impacts of environmental change are still relatively insignificant among many tourism service providers. However, of all the respondents $(n=41), 44$ percent ( $=18$ enterprises) had experienced extra expenses generated by climatic shifts. Almost half (44\%) of them were able to give cost estimations. Thus, 19.5 percent of all the respondents estimated the amount of costs. Most commonly, the extra costs were generated by the decreased sales figures. 
Though the estimated costs are seemingly low figures, it must be remembered that entrepreneurs in Finnish Lapland are mostly small businesses that may suffer significantly financially from one single weather event. For example, exceptionally warm fall weather delayed the winter sales reducing as much as 20 percent of overall sales with one company, and rain and wind had reduced sales for almost 18 percent with another activity provider in a recent year. This can be considered a significant financial impact. The greatest individual loss (in absolute terms) was generated by a weather incident, namely blizzard, when one of the main roads was blocked by snow, which prevented customers' access, and led to loss in sales. However, this particular loss in combination with other weather-related costs represents merely 0.9 percent of this company's entire annual turnover.

In another company, costs emerged from the company's own vulnerable infrastructure and decreased sales. These impacts were caused by bad weather and frequent power cuts that caused harm to electronic equipment and caused cancellations, forcing them to reduce prices. The costs represented roughly 0.8 percent of the annual turnover, whereas benefits were far more, approximately 30 percent. Other infrastructure related costs were mostly based on the increased snow-ploughing due to excessive snow or on the impacts of power cuts due to storms. One respondent indicated that the snowstorm had caused $8000 €$ additional costs in snow-ploughing but in relation to turnover, the economic impacts were insignificant $(0.3 \%)$.

The labour costs were linked with having too much workforce due to poor sales and/or having to employ new staff due to disproportionately high snowfall. In both of these occasions, the source for labour costs related with snowfall. Additional labour costs also occurred when weather forecasts failed and the weather prevented the planned operations or maintenance work. In one business, the additional labour-related costs were quoted to be several tens of thousands, but in relation to turnover, this was merely 0.1 percent. In contrast, the daily sales could increase by 100 percent in nice weather for the same company. The extra costs in safari programmes were generated by rearranging activities, changing seasons and being extra cautious with programme timings. Often, the costs were related to snow. Other costs concerning the safari programme management were fairly small, less than or around one percent, and were an inconvenience rather than a significant financial cost.

To conclude, in two occasions the negative impacts generated approximately 18-20 percent extra costs, which were both related to decrease in direct sales. For the remaining businesses, the 
increased costs were minor (app. $0.1 \%-1 \%$ ). The average cost of adaptation among the respondents who reported and evaluated the amount of costs $(n=8)$ was 5.1 percent. When calculating by sector, the average costs were the following: Retail 10.5 percent, Recreation and Programmes 6.3 percent, Accommodation and Restaurants 0.8 percent, and Combination Establishments 0.1 percent.

Sector-wise, 50 percent of Recreation and Programme service enterprises reported costs from climate and weather phenomena, while the same issue was reported in the Accommodation and Restaurant services by 42 percent of the entrepreneurs. In Retail Services, over half of the enterprises $(57 \%)$ had suffered from extra costs because of climatic and weather conditions. In the sector Other, none of the 7 businesses reported extra costs, and in Combination businesses the costs had occurred among 63 percent of the respondents. In Transport-category, the only representative $(100 \%)$ reported costs.

Insert Table 5. here.

\section{Discussion}

This paper aimed to evaluate the costs and benefits of environmental change and related (potential) adaptation measures to businesses operating in tourism destinations in two Arctic communities in Finnish Lapland. While focusing on adaptation, the issue of global environmental change and its local scale impacts were highlighted with respect to the evaluation of costs and benefits. The benefits of changing environmental (e.g. weather) conditions were concretised via changing consumption patterns and increased sales while costs were directed towards a quite specific part of business operations (e.g. certain element of infrastructure, work force and salary costs).

As the sample size was limited, analyses to identify statistically reliable differences were also limited. In addition, the turnover data covered only 80 percent of the enterprises participating in the study, which decreased the accuracy of calculations. However, some comparisons concerning the amount of extra costs and benefits and their appearance were run on the basis of sector, size of the business (annual turnover), location and the main season. Of the respondents, 44 percent stated to have experienced weather-related costs and the numerical responses specified that the average cost of adaptation was 5.1 percent. In return, the experienced benefits affected 78 percent of the entrepreneurs resulting in an average of 7.3 percent increased turnover. Socio-economic changes 
were related to infrastructure, economic issues, sales, and customer-base, and were found to affect tourism development by 88 percent of the interviewees. The most commonly referred changes in the natural environment were related to seasons, weather conditions, and flora and fauna. These were observed by the majority, namely 88 percent of the respondents.

Concerning the types of adaptation, the results show more tendencies for passive adaptation, where the decisions are made based on experiences and occurred changes. As shown above, 88 percent of the interviewees have experienced changes in their natural environment, with sentiments varying between negative and positive impacts. The experienced changes and the subsequent benefits that were felt by 78 percent of the respondents, emphasise passive adaptation. According to the both types of adaptation (reactive and passive) there is an element of learning present, which is also detectible in the results. For example the changing shoulder seasons are nowadays to some extent approached with caution. Shoulder seasons are understood as the time between high and low seasons, more specifically relating to late autumn and late spring as well as early summer. Furthermore, though snow security exists, the experience has shown that also the conditions in tourist originating regions impact the destinations.

Despite the prominence of passive adaptation, understanding emerging climatic conditions shows an element of active adaptation. Therefore, though the costs are mostly related to passive adaption there is an occasional active adaptation investment present. Occasionally the costs occur due to just struggling with the general environmental change and variability. The results signal a relatively low financial impact of environmental change related issues on tourism entrepreneurs in Lapland. However, the real costs may be far greater and the abstract notion of climate change must be taken into consideration as people are not always able to synthesise between local level issues and climate change impacts. In this sense, perhaps the changes are 'not yet serious enough'.

Also, adaptation mechanisms, and their meanings, vary according to destinations. For example, the snow-making was not considered to be an adaptation action by locals but rather a normal activity related to the unpredictability of the climatic conditions. Therefore, no specific sum was given to this activity. In tourism adaptation research, however, snow-making is regarded as one of the main adaptive mechanisms in snow-based tourism (see Haanpää et al., 2014; Träwöger, 2014).

It is crucial to remind that this paper has evaluated the costs and benefits of GEC in a tourism destination context, which leaves many larger scale and indirect impacts unconsidered. Some references to these kinds of impacts were made, such as the reliance on airport services and the 
municipality/regional level infrastructure: for example, the costs that took place when the community's infrastructure failed. The interviewed entrepreneurs were also more often able to estimate the net effect of phenomena that can be associated with climate change than phenomena that falls in category 'normal variability'. This may indicate two things: first, the phenomena relating to climate change are new and therefore registered better, and second, the net effect of normal variability evens out in time when both beneficial and detrimental climatic events fluctuate.

When identifying the combined effects of costs and benefits per sector, certain trends arise. Accommodation and Restaurant sector seems to be benefitting the most from the changes in weather fluctuations. Retail can be assessed to suffer the most along with Recreation and Programmes whereas Transport and Other sectors are only benefitting as they did not report any costs. Moreover, the Combination enterprises also seem to mainly receive benefits. This implies that diversification is an effective strategy against climate variability. Also, in relation to geographical location, Kilpisjärvi seems to benefit more than Saariselkä. Season-wise, the highest benefits take place in businesses with snow season as their main season. This contradicts to some extent with several studies which indicate vulnerability of snow-dependent tourism and resilience of the so-called summer tourism in Northern Europe (Amelung, Nicholls \& Viner, 2007; Grillakis et al., 2016; Saarinen \& Tervo, 2006). The studies show that volatile snow-conditions create unpredictability for businesses where the changing winter conditions are difficult to manage. Substituting activities in winter is far more challenging than in summer as the difference between not having snow, and having snow, is crucial (Agnew \& Viner, 2001; Saarinen \& Tervo, 2006).

Interestingly, certain phenomena may mean high costs for some sectors while others seem to benefit from their occurrence, reducing the destination-wide costs. For example, bad weather was stated to benefit Transport sector while in Retail, Accommodation and Restaurant, Recreation and Programme services this caused costs. The same applied to vast amount of snow: it benefitted Accommodation and Restaurant services and Janitorial services while Recreation and Programme services suffered. In Retail sector, both benefits and costs were registered for the same reason.

Therefore, it is important to understand that the net benefits/costs of adaptation to environmental changes may depend considerably on the scale of analysis: individual business may suffer even though at the destination scale net benefits are recorded. Another interesting factor about the Combination and Other -groups is that it could indicate emerging new professions or give information about emerging new benefitting sectors, which do not fit in the traditional categories. In 
addition, it is important to examine the relative occurrence of both costs and benefits sector-wise: the most unaffected sector in terms of costs seems to be the Other-sector while in relation to benefits Retail seems to be receiving the most benefits.

There is some indication that in terms of costs, the establishments with high turnovers ( $\geq 1000000 €$ ) were able to absorb the costs more efficiently. However, as not all businesses were comfortable with sharing information concerning their turnover, these results are only indicative. Bearing these facts in mind, it can be stated that of the interviewed business that were able to pinpoint costs, half had turnovers in the highest category with costs adding up to $0.1-0.9$ percent. However, spatial dimension of costs and benefits could add to new knowledge about environmental change and climate change. In this study, however, there were no major differences in the occurrence or amount of costs between the two study destinations even though Kilpisjärvi seemed to benefit more than Saariselkä. Furthermore, comparing the net effects of environmental change in different regions/destinations and even at different times could specify the most economically vulnerable regions and seasons. For example, a study focusing on eastern Lapland by Kaján et al. (2014) indicated that the costs of the main peak season (Christmas) adapting to climate change in relation to annual turnover are similar to this study (between 1-5\%), but that the costs in relation to seasonal turnover were as high as 250 percent. In the southern tourist destinations in Finland, adaptation to winter conditions can be expected to be even more costly (Saarinen \& Tervo, 2006) but the financial benefits are still largely unknown.

If there are alternatives replacing the outdoor activities during bad or unpredictable weather, the overall tourist experience is not necessarily negative (see also Denstadli, Jacobsen \& Lohmann, 2011). More diversified services can create more benefits to the entire community (Kaján, 2014). As the shoulder seasons are expected to lengthen, summers to suffer from more precipitation and the snow-conditions to change (see IPCC, 2014), the role of diversified industry plays a key role. However, in order to build sustainable and climate-resilient destinations, both the costs and benefits should be equally divided so that one sector or single enterprise does not take the full burden of costs, nor gain the full benefits at the expense of others. Again, understanding the importance of the scale of analysis is emphasised.

The advantage of establishing the current net adaptation costs lies in their seemingly simple approach, which could be communicated to tourism entrepreneurs relatively easily. This means that the quantified approach may be more easily understood. The used time span of five years is not 
necessarily long enough in a scientific sense for evaluating the impacts of environmental change, or especially global climate change, but in the context of tourism industry, shorter time spans are often needed due to the nature of the businesses and its planning and management cycles (see Lepy et al., 2014; Saarinen \& Tervo 2006). However, in addition to short-term adaptation measures, a neglected focus on mitigation in tourism operations should be emphasized in the future in both tourism systems and at the destination scale. According to Stern (2006), for example, the cost of mitigation is only one percent of the GDP, while the cost of non-mitigation might be as high as 20 percent of the GDP. Thus, while adaptation is perhaps perceived more acute for the successful management of tourism operations in changing environmental conditions, the most cost-effective way of reacting to the challenge of climate change is a pro-active approach focusing on mitigation. Obviously, the time span of the benefits of mitigation measures is much longer and focusing on too distant future for SME tourism businesses compared with the adaptation as an investment with faster potential returns.

This refers to the basic challenge in climate change adaptation and mitigation planning: the future units, systems, changes and capacities to respond are not really known, especially when the tourism industry is as dynamic as it is. This relates a so-called time horizon problem, which refers to the tendencies of people and organizations to focus on near, rather than medium and long term futures (see Orlove, 2010). Human actors place low value and, thus, action preference to issues that take place in the distant future. The time horizon problem may also manifest itself as an unsustainable adaptation choice and/or the lack of interest in mitigation. This makes it challenging to implement the known or estimated future costs to present day decisions and practices (e.g., in tourism-climate change relations)(Saarinen, 2014). As the study has shown, evaluating and understanding the impacts of climate change in different time and spatial scales is not only pertinent but also challenging. In addition, it is important to acknowledge the intertwined nature of any changes in societies and international relations, due to which the drawing of direct conclusions is somewhat difficult.

\section{Conclusions}

Current emphasis on neoliberal governance highlights the need to understand how businesses operate, adapt and perceive the potential or existing costs and benefits of global environmental change. Adaptation is necessary as climate change has advanced, or is about to reach, the stage 
where adaptation is already required. The results of this study indicate that the current benefits of environmental change and adaptation exceed the costs in local scale. The currently occurring weather phenomena generate more financial income for the local SMEs than produce additional costs. In addition, the results show particular sectoral vulnerabilities. However, the net benefits are attained by passive, rather than active, adaptation efforts. This knowledge may assist in developing more resilient destinations and businesses in and outside tourism. The results also reveal that there may be other benefitting sectors outside the tourism sphere, which role may increase as climate change proceeds.

Overall, however, these results indicate a potential challenge in the current modes of governance emphasising a more market-driven approaches in climate change responses mainly based on a local scale responsibilities. As the environmental change in the Arctic is generally seen by the businesses as beneficial and adaptation measures as a profitable investments for the operations, what would then be the incentives for the industry to be pro-active and, thus, more responsible in the mitigation? The adaptation actions are also hindered by the relatively short planning cycles among SMEs. All this raises critical questions against the current emphasis on decentralisation of adaptation to the lowest level of governance and seeing adaptation mainly as a local scale responsibility, as local level often has very limited capacity and resources to plan and implement for (long-term) adaptation.

Though this paper has focused on measures that mainly deal with adaptation, most probably only the combined efforts of effective adaptation and mitigation can safeguard more sustainable futures for the Arctic communities living and working in fragile environments that are expected to be greatly impacted by the global climate change. For this, a more regulative and long-term mode of governance by the public sector and/or public-private partnerships is likely needed to guide the tourism industry to respond locally to the challenge of global environmental change.

Understandings of impacts of global environmental change are influenced by varying perceptions of change itself, differing time and spatial scales, unpredictable business management issues and estimations of advantages and disadvantages of change.

\section{References}


Aall, C. (2012). The early experiences of local climate change adaptation in Norwegian compared with that of local environmental policy, Local Agenda 21 and local climate change mitigation, Local Environment 17, 579-595, DOI:10.1080/13549839.2011.631992

Aall, C., \& Hoyer, K.G. (2005). Tourism and climate change adaptation: the Norwegian case'. In C.M. Hall, \& J. Higham (Eds.), Tourism, Recreation and Climate Change (pp. 209-221). Clevedon: Channel View Publications.

Adger, N. (2003). Social capital, collective action, and adaptation to climate change. Economic Geography 79(4), 387-404. DOI:10.1111/j.1944-8287.2003.tb00220.x

Adger, N., Arnell, N., \& Tompkins, E. (2005). Successful adaptation to climate change across scales. Global Environmental Change 15, 77-86. DOI:10.1016/j.gloenvcha.2004.12.005

Agnew, M. D., \& Viner, D. (2001). Potential impacts of climate change on international tourism. Tourism and Hospitality Research 3(1), 37-60. Retrieved from http://www.jstor.org/stable/23743849Amelung, B., Nicholls, S., \& Viner, D. (2007). Implications of global climate change for tourism flows and seasonality. Journal of Travel Research 45, 285296. DOI:10.1177/0047287506295937

Amore, A. \& Hall, C. M. (2016). From governance to meta-governance in tourism? Reincorporating politics, interests and values in the analysis of tourism governance. Tourism Recreation Research 41(2), 109-122. DOI:10.1080/02508281.2016.1151162

Armitage, D. R., Plummer, R., Berkes, F., Arthur, R. I., Charles, A. T., Davidson-Hunt, I. J., ... \& Wollenberg, E. K. (2009). Adaptive co-management for social-ecological complexity. Frontiers in Ecology and the Environment 7(2), 95-102. DOI:10.1890/070089

Becken, S. (2012). Measuring the effect of weather on tourism: A destination- and activity-based analysis. Journal of Travel Research 52(2), 156-167. DOI:10.1177/0047287512461569

Becken, S., \& Clapcott, R. (2011). National tourism policy for climate change. Journal of Policy Research in Tourism, Leisure and Events 3(1), 1-17. DOI:10.1080/19407963.2011.539378

Berkes, F., Colding, J., \& Folke, C. (2000). Rediscovery of traditional ecological knowledge as adaptive management. Ecological applications, 10(5), 1251-1262. DOI:10.2307/2641280

Bramwell, B., \& Lane, B. (2011). Critical research on the governance of tourism and sustainability. Journal of Sustainable Tourism 19 (4-5), 411-421. DOI:10.1080/09669582.2011.580586. 
Brouder; P., \& Lundmark, L. (2011). Climate change in Northern Sweden: Intra-regional perceptions of vulnerability among winter-oriented tourism businesses. Journal of Sustainable Tourism 19(8), 919-933. DOI:10.1080/09669582.2011.573073

Cheablam, O., \& Shrestha, R. P. (2015). Climate change trends and its impact on tourism resources in Mu Ko Surin Marine National Park, Thailand. Asia Pacific Journal of Tourism Research 20(4), 435-454. DOI:10.1080/10941665.2014.904803

Csete, M., \& Szécsi, N. (2015). The role of tourism management in adaptation to climate change - a study of a European inland area with a diversified tourism supply. Journal of Sustainable Tourism 23(3), 477-496. DOI:10.1080/09669582.2014.969735

Dawson J., Scott, D., \& McBoyle, G. (2009). Climate change analogue analysis of ski tourism in the northeastern USA. Climate Research 39: 1-9. DOI:10.3354/cr00793

Dawson, J., \& Scott, D. (2013). Managing for climate change in the alpine ski sector. Tourism Management 35, 244-254. DOI: 10.1016/j.tourman.2012.07.009

Denstadli, J. M., Jacobsen, J. K. S., \& Lohmann, M. (2011). Tourist perceptions of summer weather in Scandinavia. Annals of Tourism Research 38, 920-940. DOI:10.1016/j.annals.2011.01.005

Dubois, G., \& Ceron, J-P. (2006). Tourism and climate change: proposals for a research agenda. Journal of Sustainable Tourism 14(4), 399-415. DOI:10.2167/jost539.0

Enontekiön matkailualueen turvallisuussuunnitelma (2013). (Tourism security plan for Enontekiö region). Matkailualan tutkimus- ja koulutusinstituutti. Available from http://www.enontekio.fi/media/enontekif6n_matkailualueen_turvallisuussuunnitelma_11.3.2013.pdf (accessed 11.5.2015)

Eriksen, S. H., Nightingale, A. J., \& Eakin, H. (2015). Reframing adaptation: The political nature of climate change adaptation. Global Environmental Change 35, 523-533.

DOI:10.1016/j.gloenvcha.2015.09.014

Espiner, S., Orchiston, C., \& Higham, J. (2017). Resilience and sustainability: a complementary relationship? Towards a practical conceptual model for the sustainability-resilience nexus in tourism. Journal of Sustainable Tourism (in press). DOI:10.1080/09669582.2017.1281929

Ford, J. D., \& King, D.(2015). A framework for examining adaptation readiness. Mitigation and Adaptation Strategies for Global Change 20(4), 505-526. DOI:10.1007/s11027-013-9505-8 
Ford, J. D., Keskitalo, E. H. C., Smith, T., Pearce, T., Berran-Ford, L., Duerden, F., \& Smit, B. (2010). Case study and analogue methodologies in climate change vulnerability research. Wiley Interdisciplinary Reviews: Climate Change 1(3), 374-392. DOI:10.1002/wcc.48

Füssel, H.-M., \& Klein, R. J. T. (2006). Climate change vulnerability assessments: An evolution of conceptual thinking. Climatic Change 75, 301-329. DOI: 10.1007/s10584-006-0329-3

Grillakis, M. G., Koutroulis, A. G., Seiradakis, K. D., \& Tsanis, I. K. (2016). Implications of $2{ }^{\circ}$ C global warming in European summer tourism. Climate Services 1, 30-38. DOI:

10.1016/j.cliser.2016.01.002

Gössling, S. (2002). Global environmental consequences of tourism. Global Environmental Change 12, 283-302. DOI:10.1016/S0959-3780(02)00044-4

Gössling, S., \& Hall, C. M. (Eds.) (2006). Tourism and Global Environmental Change: Ecological, Social, Economic and Politic Interrelationships. London: Routledge.

Haanpää, S., Juhola, S., \& Landauer, M. (2014): Adapting to climate change: perceptions of vulnerability of down-hill ski area operators in Southern and Middle Finland. Current Issues in Tourism 18(10), 966-978. DOI:10.1080/13683500.2014.892917

Hall, C. M. (2006). New Zealand tourism entrepreneur attitudes and behaviours with respect to climate change adaptation and mitigation. International Journal of Innovation and Sustainable Development 1(3), 229-237. DOI:10.1504/IJISD.2006.012424

Hall, C. M. (2011). A typology of governance and its implications for tourism policy analysis. Journal of Sustainable Tourism 19(4-5), 437-457. DOI:10.1080/09669582.2011.570346

Hall, C.M. (2013). Framing behavioural approaches to understand and governing sustainable tourism consumption. Journal of Sustainable Tourism 21(7), 1091-1109.

DOI:10.1080/09669582.2013.815764

Hoffmann, V. H., Sprengel, D. C., Ziegler, A., Kolb, M., \& Abegg, B. (2009). Determinants of corporate adaptation to climate change in winter tourism: An econometric analysis. Global Environmental Change 19(2), 256-264. DOI:10.1016/j.gloenvcha.2008.12.002

Holden, A. (2006). Environment and Tourism. London: Routledge.

Hopkins, D. (2014). The sustainability of climate change adaptation strategies in New Zealand's ski industry: a range of stakeholder perceptions. Journal of Sustainable Tourism 22(1), 107-126.

DOI:10.1080/09669582.2013.804830 
Ingirige, M. J. B., Jones, K., \& Proverbs, D. (2008). Investigating SME resilience and their adaptive capacities to extreme weather events: A literature review and synthesis. In Haigh, R. \& Amaratunga, D. (Eds.): Conference Proceedings of the CIB International Conference on Building Education and Research: Building Resilience (BEAR) 2008, Kandalama, Sri Lanka, $11^{\text {th }}-15^{\text {th }}$ February 2008, 582-593. Available from http://www.irbnet.de/daten/iconda/CIB11298.pdf (accessed 12.3.2016).

IPCC (2014). IPCC WGII AR5 Glossary. Available from http://ipccwg2.gov/AR5/images/uploads/WGIIAR5-Glossary_FGD.pdf (accessed 25.4.2016).

Jessop, B. (2002). Liberalism, neoliberalism, and urban governance: A state-theoretical perspective. Antipode 34(3), 452-472. DOI:10.1111/1467-8330.00250

Kaján, E. (2014). Arctic tourism and sustainable adaptation: community perspectives to vulnerability and climate change. Scandinavian Journal of Hospitality and Tourism 14(1), 60-79. DOI:10.1080/15022250.2014.886097

Kaján, E., \& Saarinen, J. (2013). Tourism, climate change and adaptation: A review. Current Issues in Tourism 16(2), 167-195. DOI:10.1080/13683500.2013.774323

Kaján, E., Tervo-Kankare, K., \& Saarinen, J. (2014). Cost of adaptation to climate change in tourism: Methodological challenges and trends for future studies in adaptation. Scandinavian Journal of Hospitality and Tourism 15(3), 311-317. DOI:10.1080/15022250.2014.970665

Kelly, P. M., \& Adger, W. N. (2000). Theory and practice in assessing vulnerability to climate change and facilitating adaptation. Climatic Change 47(4), 325-352.

DOI:10.1023/A:1005627828199

Laatutiimi (2014). Saariselän alueen laatukäsikirja (A handbook of quality for Saariselkä region). Unpublished guide for regions' enterprises. Available from http://www.saariselka.fi/sisalto/laatu/laatu (accessed 22.2.2016).

Lépy, É., Heikkinen, H. I., Karjalainen, T. P., Tervo-Kankare, K., Kauppila, P., Suopajärvi, T., Ponnikas, J., Siikamäki, P., \& Rautio, A. (2014). Multidisciplinary and participatory approach for assessing local vulnerability of tourism industry to climate change. Scandinavian Journal of Hospitality and Tourism 14(1), 41-59. DOI:10.1080/15022250.2014.886373

Lew, A.A. (2014). Scale, change and resilience in community tourism planning. Tourism Geographies 16, 14-22. DOI:10.1080/14616688.2013.864325 
Marshall, G. (2008). Nesting, subsidiarity, and community-based environmental governance beyond the local scale. International Journal of the Commons 2 (1), 75-97.

DOI:http://doi.org/10.18352/ijc.50

Matasci, C., Kruse, S., Barawid, N., \& Thalmann, P. (2014). Exploring barriers to climate change adaptation in the Swiss tourism sector. Mitigation and Adaptation Strategies for Global Change 19(8), 1239-1254. DOI:10.1007/s11027-013-9471-1

Mathieson, A., \& G. Wall (1982). Tourism: Economic, Physical and Social Impacts. London: Longman.

Morrison, C., \& Pickering, C. M. (2013). Perceptions of climate change impacts, adaptation and limits to adaption in the Australian Alps: the ski-tourism industry and key stakeholders. Journal of Sustainable Tourism 21(2), 173-191. DOI:10.1080/09669582.2012.681789

Nalau, J., Preston, B.L., \& Maloney, M.C. (2015). Is adaptation a local responsibility? Environmental Science \& Policy 48, 89-98. DOI:10.1016/j.envsci.2014.12.011

Nicholls, S., Holecek, D. F., \& Noh, J. (2008). Impact of weather variability on golfing activity and implications of climate change. Tourism Analysis 13(2), 117-130.

DOI: $10.3727 / 108354208785664256$

Orlove, B. (2010). Time horizons and climate change. Weather, Climate, and Society, 2(1), 5-7. DOI:10.1175/2009WCAS1111.1

Pelling, M. (2011). Adaptation to Climate Change: From Resilience to Transformation. London: Routledge.

Pielke, R. A. (1998). Rethinking the role of adaptation in climate policy. Global Environmental Change 8(2), 159-170. DOI:10.1016/S0959-3780(98)00011-9

Rauken, T., \& Kelman, I. (2012). The indirect influence of weather and climate change on tourism businesses in Northern Norway. Scandinavian Journal of Hospitality and Tourism 12(3), 197-214. DOI:10.1080/15022250.2012.724924

Rauken, T., Kelman, I., Jacobsen, J.K.S., \& Hovelsrud, G. K. (2010). Who can stop the rain? Perceptions of summer weather effects among small tourism businesses. Anatolia 21(2), 289-304. DOI:10.1080/13032917.2010.9687104

Reddy, M. V., \& Wilkes, K. (Eds.)(2013). Tourism, Climate Change and Sustainability. Oxon: Routledge. 
Rhodes, R. (1996). The new governance: Governing without government. Political Studies 44(4), 652-667. DOI:10.1111/j.1467-9248.1996.tb01747.x

Rutty, M., \& Scott, D. (2010). Will the Mediterranean become "too hot" for tourism? A reassessment. Tourism and Hospitality Planning \& Development 7(3), 267-281.

DOI:10.1080/1479053X.2010.502386

Rutty, M., Scott, D., Johnson, P., Pons, M., Steiger, R., \& Vilella, M. (2017). Using ski industry response to climatic variability to assess climate change risk: An analogue study in Eastern Canada. Tourism Management 58, 196-204. DOI:10.1016/j.tourman.2016.10.020

Saarinen, J. (2003). The regional economics of tourism in Northern Finland: the socio-economic implications of recent tourism development and future possibilities for regional development. Scandinavian Journal of Hospitality and Tourism 3(2), 91-113. DOI:10.1080/15022250310001927

Saarinen, J. (2004). 'Destinations in change': the transformation process of tourist destinations. Tourist Studies 4, 161-179.DOI: 10.1177/1468797604054381

Saarinen, J. (2014). Critical sustainability: setting the limits to growth and responsibility in tourism. Sustainability 6(11), 1-17. DOI:10.3390/su6010001

Saarinen, J., \& Tervo, K. (2006). Perceptions and adaptation strategies of the tourism industry to climate change: The Case of Finnish nature-based tourism entrepreneurs. International Journal of Innovation and Sustainable Development 1(3), 214-228. DOI:10.1504/IJISD.2006.012423

Scott, D., \& Becken, S. (2010). Adapting to climate change and climate policy: Progress, problems and potentials. Journal of Sustainable Tourism 18(3), 283-295. DOI:10.1080/09669581003668540

Scott, D., Hall, C.M., \& Gössling, S. (2012). Tourism and Climate Change: Impacts, Adaptation \& Mitigation. London: Routledge.

Scott A., Higham, J. Gössling, S., \& Peeters P. (Eds.)(2013). Understanding and Governing Sustainable Tourism Mobility: Psychological and Behavioural Approaches. London: Routledge.

Shih, C., Nicholls, S., \& Holecek, D. F. (2008). Impact of weather on downhill ski lift ticket sales. Journal of Travel Research 47(3), 359-372. DOI:10.1177/0047287508321207

Smit, B., \& Wandel, J. (2006). Adaptation, adaptive capacity and vulnerability. Global Environmental Change 16, 282-292. DOI:10.1016/j.gloenvcha.2006.03.008 
Smit, B., Burton, I., Klein, R. J., \& Wandel, J. (2000). An anatomy of adaptation to climate change and variability. Climatic Change 45(1), 223-251. DOI:10.1023/A:1005661622966

Statistics Finland (2014). Enterprises: Establishments by postal code. PX-Web Statfin. Available from http://pxnet2.stat.fi/PXWeb/pxweb/en/StatFin/ (accessed 15.12.2015).

Steiger, R., \& Stötter, J. (2013). Climate change impact assessment of ski tourism in Tyrol. Tourism Geographies 15(4), 577-600. DOI:10.1080/14616688.2012.762539

Stern, N. H. (2006). Stern Review: The economics of climate change (Vol. 30). London: HM Treasury.

Tervo, K. (2008). The operational and regional vulnerability of winter tourism to climate variability and change: the case of the Finnish nature-based tourism entrepreneurs. Scandinavian Journal of Hospitality and Tourism 8(4), 317-332. DOI:10.1080/15022250802553696

Tervo-Kankare, K. (2011). The consideration of climate change at the tourism destination level in Finland: Coordinated collaboration or talk about weather? Tourism Planning \& Development 8(4), 399-414. DOI:10.1080/21568316.2011.598180

Tervo-Kankare, K. (2012). Climate change awareness and adaptation in nature-based winter tourism. Regional and operational vulnerabilities in Finland. Nordia Geographical Publications 41(2).

Trawöger, L. (2014). Convinced, ambivalent or annoyed: Tyrolean ski tourism stakeholders and their perceptions of climate change. Tourism Management 40, 338-351.

DOI:10.1016/j.tourman.2013.07.010

UNCCC (2015). The Paris Agreement. Available from http://unfccc.int/files/meetings/paris_nov_2015/application/pdf/paris_agreement_english_.pdf (accessed 15.4.2016).

UNWTO (2015). UNWTO Tourism Highlights 2015 Edition. Available from http://www.eunwto.org/doi/pdf/10.18111/9789284416899 (accessed 22.4.2016).

Veal, A. J. (2006). Research Methods for Leisure and Tourism: A Practical Guide. Harlow: Pearson Education. 
Wall, G., Harrison, R., Kinnaird, V., McBoyle, G., \& Quinlan, C. (1986). The implications of climate change for camping in Ontario. Journal Recreation Research Review, 13, 50-60.

Walters, C.J. (1986). Adaptive Management of Renewable Resources. Mc Graw Hill: New York.

White, M. A., Cornett, M. W., \& Wolter, P. T. (2017). Two scales are better than one: Monitoring multiple-use northern temperate forests. Forest Ecology and Management 384, 44-53.

DOI:10.1016/j.foreco.2016.10.032

Wolfsegger, C., Gössling, S., \& Scott, D. (2008). Climate change risk appraisal in the Austrian ski industry. Tourism Review International 12(1), 13-23. DOI:10.3727/154427208785899948 